Kredo 4 (2020)
KREDO: Jurnal Ilmiah Bahasa dan Sastra
Terakreditasi Sinta 4 berdasarkan Keputusan Direktorat
Jenderal Penguatan Riset dan Pengembangan,
Kementerian Riset, Teknologi dan Pendidikan Tinggi
Republik Indonesia
Nomor: 23/E/KPT/2019. 08 Agustus 2019
https://jurnal.umk.ac.id/index.php/kredo/index

\title{
KEEFEKTIFAN PENERAPAN METODE BRAINSTORMING UNTUK MENINGKATKAN KEMAMPUAN MAHASISWA DALAM MENULIS TEKS BERITA
}

\author{
Darningwati', Yunda Lestari ${ }^{2}$, Bambang Sulistyo ${ }^{3}$ \\ darning_wati@fkip.unbara.ac.id
}

Universitas Baturaja, Indonesia

Info Artikel
Sejarah Artikel
Diterima
6 November 2019
Disetujui
4 Juni 2020
Dipublikasikan
28 Oktober 2020
\begin{abstract}
:
The problem in this study was to find out how the ability of 6th semester students of the Indonesian Language and Literature Study Program, FKIP, Baturaja University to write news texts before and after using the brainstorming learning method. Is the brainstorming learning method more effective than conventional method. The purpose of this study was to describe the effectiveness of the braimstorming learning method in improving the students' ability to write news texts. The method used in this research is an experimental method using a pre-experimental design. The population in this study were all 6th semester students, totaling 137 students. The sample of 27 people was taken using the sample random sampling method. Based on the results of data analysis, the post-test mean score was 84.44 and the pre-test mean score was 64.44 . The t test result states : that tcount >ttable (0.05: 27). Based on the results of the t test, it can be seen that there are differences in the ability to write news texts between the use of conventional learning methods and the brainstorming method. The post-test score using the brainstorming learning method is higher than the pre-test score using the conventional method. So it can be concluded that learning using the brainstorming method is more effective in learning to write news texts.
\end{abstract}

:

Keywords method,news text, writing skills

Kata Kunci

keterampilan menulis, metode brainstorming, teks berita

\begin{abstract}
Abstrak
Masalah dalam penelitian ini adalah bagaimanakah kemampuan mahasiswa semester VI Program Studi Pendidikan Bahasa dan Sastra Indonesia FKIP Universitas Baturajamenulis teks berita
sebelum dan sesudah menggunakan metode pembelajaran brainstorming. Apakah metode pembelajaran brainstorminglebih efektif daripada metode konvensional. Tujuandari penelitianini untukmendeskripsikan efektivitas metode pembelajaran braimstorming dalam meningkatkan kemampuan menulis teks berita pada mahasiswa. Metode yangdigunakandalam penelitian iniadalahmetode eksperimendenganmenggunakan desain pra-eksperimental.Populasi dalam penelitian ini adalah seluruh mahasiswa semester VI yang berjumlah 137 mahasiswa. Adapun sampel berjumlah 27 orang diambil dengan menggunakan metode sample random sampling. Berdasarkanhasil analisisdata,rata-rata post-test adalah 84,44 dan skor rata-rata pre-test adalah 64,44 . Hasil uji $\mathrm{t}$ menyatakan bahwa $\mathrm{t}_{\text {hitung }}>\mathrm{t}_{\text {tabel }}(0.05: 27)$. Berdasarkan hasil uji $\mathrm{t}$ dapat diketahui bahwa ada perbedaan kemampuan menulis teks berita antara penggunaan metode pembelajaran konvensional dan metode brainstorming. Nilai post-test yang menggunakan metode pembelajaran brainstorming lebih tinggi dari nilai pre-testyang menggunakan metode konvensional. Jadidapatdisimpulkanbahwapembelajaran dengan menggunakan metode brainstorming lebih efektif dalam pembelajaran menulis teks berita.
\end{abstract}

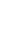

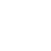

\section{PENDAHULUAN}

Dewasa ini, persaingan dalam dunia kerja sudah sangat ketat. Oleh karena itu, perguruan tinggi harus mempersiapkan lulusannya untuk dapat bersaing dalam dunia kerja sesuai dengan bidangnya. Guru atau dosen dituntun untuk dapat melaksanakan pengajaran dan dapat menentukan bentuk interaksi yang tepat sesuai materi yang diajarkan (Emilda, 2019). Guru dan dosen harus terus berinovasi untuk selalu mencipatkan suasana kelas yang menarik dalam proses belajar mengajar. Program Studi Pendidikan Bahasa dan Sastra Indonesia (PBSI FKIP UNBARA) sebagai salah satu program studi yang ada di

\section{2 | Jurnal Kredo}

Vol. 4 No. 1 Oktober 2020 


Kredo 4 (2020)
KREDO: Jurnal Ilmiah Bahasa dan Sastra
Terakreditasi Sinta 4 berdasarkan Keputusan Direktorat
Jenderal Penguatan Riset dan Pengembangan,
Kementerian Riset, Teknologi dan Pendidikan Tinggi
Republik Indonesia
Nomor: 23/E/KPT/2019. 08 Agustus 2019
https://jurnal.umk.ac.id/index.php/kredo/index

kabupaten harus ikut mempersiapkan lulusannya agar dapat bersaing di dunia kerja di dalam dan luar kabupaten Ogan Komering Ulu. Salah satu hal yang tidak terlepas dari kurikulum program studi PBSI adalah empat keterampilan berbahasa. Empat keterampilan berbahasa merupakan keterampilan yang harus dikuasai oleh mahasiswa dan lulusan Program Studi.

Salah satu keterampilan yang harus dikuasai mahasiswa adalah menulis. Menulis memiliki peran yang sangat penting karena dengan menulis maka seseorang dapat meningkatkan kecerdasan, mengembangkan daya kreativitas, menumbuhkan keberanian, serta merangsang kemauan dan mengumpulkan informasi (Widyawati, 2019). Keterampilan menulis tidak akan datang secara otomatis, melainkan harus melalui latihan dan praktek yang banyak dan teratur. Melalui kegiatan menulis seseorang dapat melahirkan pikiran, perasaan, ide-idenya, dan persepsinya mengenai semua hal di dalam kehidupan ini, sehingga pembaca dapat memahami apa yang diinginkan penulisnya.

Berdasarkan pengamatan dosen mata kuliah menulis pada hari Selasa, tanggal 22 Januari 2019 dan hasil belajar menulis mahasiswa berupa nilai rata-rata evaluasi menulis yaitu sebesar 58,13 sehingga diketahui bahwa mahasiswa Program Studi PBSI masih banyak yang belum terampil menulis. Padahal sebagai mahasiswa PBSI mereka harus memiliki keterampilan tersebut. Para mahasiswa semester VI Angkatan tahun 2016/2017 sudah belajar mata kuliah Dasar-dasar Keterampilan Menulis, Pengembangan Keterampilan Menulis, dan Menulis Kreatif. Melalui mata kuliah tersebut mahasiswa sudah memiliki dasar pengetahuan dan pemahaman mengenai menulis. Fenomena ini juga sejalan dengan pengamatan Lestari (2019:74) dalam penelitiannya bahwa banyak ditemui paragraf pada karangan mahasiswa tidak mempunyai ide pokok atau merupakan bagian dari paragraf sebelumnya.

Penelitian mengenai metode brainstorming juga dilakukan oleh Asni Harianti dan Yola Margareta (2014) dengan judul "Pengembangan Kreativitas Mahasiswa dengan Menggunakan Metode Brainstorming dalam Mata Kuliah Kewirausahaan". Adapun perbedaan penelitian ini dengan penelitian terdahulu adalah pada tujuan penelitian. Penelitian ini bertujuan untuk mendeskripsikan efektifitas metode pembelajaran brainstorming dalam meningkatkan kemampuan menulis teks berita pada mahasiswa sedangkan penelitian terdahulu bertujuan untuk mengetahui apakah terdapat peningkatan kreativitas mahasiswa setelah mendapatkan perlakuan metode brainstorming dan apakah terdapat perbedaan pengembangan kreativitas mahasiswa antara kelompok yang diberi perlakuan metode brainstorming dengan kelompok yang tidak diberi perlakuan. Sedangkan persamaan penelitiannya adalah sama-sama menggunakan metode brainstorming dalam pembelajaran.

Salah satu keterampilan menulis yang dapat digunakan mahasiswa adalah menulis teks berita. Melalui teks berita, mahasiswa dapat menuliskan semua peristiwa yang dilihat dan diamatinya. Selain itu, berdasarkan silabus mata kuliah menulis, mahasiswa sudah diajarkan menulis teks berita. 


\begin{tabular}{|c|c|c|} 
Kredo 4 (2020) \\
KREDO: Jurnal Ilmiah Bahasa dan Sastra \\
Terakreditasi Sinta 4 berdasarkan Keputusan Direktorat \\
Jenderal Penguatan Riset dan Pengembangan, \\
Kementerian Riset, Teknologi dan Pendidikan Tinggi \\
Republik Indonesia \\
Nomor: 23/E/KPT/2019. 08 Agustus 2019 \\
https://jurnal.umk.ac.id/index.php/kredo/index
\end{tabular}

Teks berita merupakan ungkapan pikiran manusia yang lengkap yang di dalamnya memiliki situasi dan konteks dapat berwujud tulis maupun lisan (Alfarisi dan Suseno, 2019). Berita adalah sajian informasi mengenai suatu peristiwa yang sedang atau telah terjadi. Berita dapat disajikan melalui informasi lisan ataupun tulisan di media massa baik cetak ataupun elektronik seperti surat kabar, majalah, tabloid, televisi, radio, dan internet. Dalam penulisan berita harus mengandung unsur $5 \mathrm{~W}+1 \mathrm{H}$ yaitu what (peristiwa apa yang terjadi, why (mengapa peristiwa terjadi), where (dimana peristiwa terjadi), who (siapa yang terlibat), when (kapan peristiwa terjadi), dan how (bagaimana peristiwa terjadi) (Rohmadi, 2011).

Selain itu, merujuk dari pembelajaran Program Studi PBSI yang sudah berbasis SCL (Student Centered Learning), maka peneliti juga melakukan penelitian dalam bentuk eksperimen menggunakan metode brainstorming. Dengan metode brainstrorming diharapkan dapat membantu mahasiswa menjadi lebih aktif. Kelebihan dari model ini adalah mahasiswa tidak terpaku pada wacana yang ada di buku teks, melainkan mereka diajak untuk berpikir kritis dalam menyelesaikan masalah yang ada dalam lingkup kehidupan sekitar mahasiswa. Melalui pembelajaran brainstorming, mahasiswa akan diberikan sebuah masalah. Kemudian dosen membagi mahasiswa dalam kelompok. Mahasiswa yang telah dibagi kelompoknya kemudian berdiskusi bersama mencari penyebab permasalahan. Sehubungan dengan uraian di atas, maka masalah dalam penelitian ini dirumuskan sebagai berikut. (1) bagaimanakah kemampuan mahasiswa Program Studi PBSI menulis teks berita sebelum menggunakan metode pembelajaran brainstorming?; (2) bagaimanakah kemampuan mahasiswa Program Studi PBSI menulis teks berita setelah menggunakan metode pembelajaran brainstorming?; Apakah pembelajaran brainstorming efektif dalam meningkatkan kemampuan mahasiswa Program Studi PBSI menulis teks berita. Adapun tujuan penelitian ini adalah (1) mendeskripsikan kemampuan mahasiswa Program Studi PBSI menulis teks berita sebelum menggunakan metode pembelajaran brainstorming?; (2) mendeskripsikan kemampuan mahasiswa Program Studi PBSI menulis teks berita setelah menggunakan metode pembelajaran brainstorming?; (3) mendeskripsikan keefektifan pembelajaran brainstorming dalam menulis teks berita.

\section{KAJIAN TEORI}

\section{A. Pengertian Menulis}

Menurut Awi (2011:3), "Menulis tidak sekadar aktivitas fisik, tetapi juga ekspresi diri dalam kendali hati dan otak yang menuntut latihan berkesinambungan dan terpola secara sistematis. Sejalan dengan pendapat tersebut menurut Suparno (2002:3), "Menulis dapat didefinisiskan sebagai suatu kegiatan penyampaian pesan (komunikasi) dengan menggunakan bahan tulis sebagai alat atau medianya.

\section{B. Manfaat Menulis}

Menurut Suparno (2002:4), terdapat begitu banyak manfaat yang dapat dipetik dari menulis di antaranya untuk

\section{4 | Jurnal Kredo}

Vol. 4 No. 1 Oktober 2020 


Kredo 4 (2020)
KREDO: Jurnal Ilmiah Bahasa dan Sastra
Terakreditasi Sinta 4 berdasarkan Keputusan Direktorat
Jenderal Penguatan Riset dan Pengembangan,
Kementerian Riset, Teknologi dan Pendidikan Tinggi
Republik Indonesia
Nomor: 23/E/KPT/2019. 08 Agustus 2019
https://jurnal.umk.ac.id/index.php/kredo/index

meningkatkan kecerdasan, mengembangkan daya inisiatif dan kreativitas, menumbuhkan keberanian, dan mendorong kemauan dan kemampuan dalam mengumpulkan informasi.

\section{Pengertian Berita}

Menurut Awi (2011:19), "Berita adalah semua tulisan yang bertolak dari fenomena dan peristiwa. Selanjutnya menurut Rosidi (2009:84), "Berita merupakan sebuah tulisan yang menyajikan sebuah peristiwa/kejadian penting yang menjadi bentuk tulisan utama dalam media massa". Sehubungan dengan pendapat ahli di atas dapat diketahui bahwa teks berita adalah sebuah tulisan yang menyajikan peristiwa/kejadian penting berdasarkan fenomena yang terjadi.

\section{Jenis Berita}

Menurut Jauhari (2012:158), berita di media massa di bagi menjadi tiga kategori yaitu:

\section{Reportase Investigasi}

Reportase investigasi adalah metode pencarian berita secara mendalam, mendetail, tuntas, serta dapat dipertanggungjawabkan kebenarannya. Reportase ini merupakan kegiatan peliputan untuk mencari, menemukan, dan menyampaikan fakta-fakta adanya pelanggaran, kesalahan, penyimpangan, atau kejahatan yang merugikan kepentingan umum dan masyarakat.

\section{In Dept Reporting}

In Dept Reporting adalah jenis penulisan berita secara mendalam dan biasanya tidak digunakan untuk membongkar satu masalah. Ciri menonjolnya, berita tidak basi karena tidak mengikuti trending topik. Disebut berita mendalam, karena proses penggalian datanya memerlukan perencanaan, persiapan matang, dan analisa yang mendalam. Laporan yang hendak diberitakannya memiliki nilai berita yang berat, baik dari segi fakta, penggalian data, dan dampaknya kepada masyarakat umum.

\section{Straigh news}

Straigh news adalah jenis berita yang disampaikan secara langsung, biasanya struktur penulisan dengan piramida terbalik. Pada berita langsung hal-hal yang terpenting disajikan pada pokok berita, sedangkan bagian lainya pada bagian uraian dengan urutan makin lama makin kurang penting. Biasa disebut berita seketika karena mengejar penyampaian segera. Oleh karena itu, berita kurang mendalam jika hanya mengandung unsur utama $5 \mathrm{~W}+1 \mathrm{H}$ saja. Melalui pemaparan tersebut dapat disimpulkan bahwa berita langsung adalah berita yang memiliki nilai lebih dari segi aktualitas dan kepentingan atau amat penting segera diketahui pembaca. Berisi informasi peristiwa khusus yang terjadi secara tiba-tiba.

\section{E. Unsur Berita}

Menurut Cahya (2012:17), suatu berita harus berisi informasi yang melengkapi unsur $5 \mathrm{~W}+1 \mathrm{H}$ yang terdiri dari What (apa), Who (siapa), Where (di mana), When (kapan), Why (mengapa), dan How (bagaimana). Melalui lima unsur berita ini, penulis dapat mengumpulkan informasi dari berbagai sumber dan menyusunnya menjadi suatu berita. 


\begin{tabular}{|c|c|c|} 
Kredo 4 (2020) \\
KREDO: Jurnal Ilmiah Bahasa dan Sastra \\
Terakreditasi Sinta 4 berdasarkan Keputusan Direktorat \\
Jenderal Penguatan Riset dan Pengembangan, \\
Kementerian Riset, Teknologi dan Pendidikan Tinggi \\
Republik Indonesia \\
Nomor: 23/E/KPT/2019. 08 Agustus 2019 \\
https://jurnal.umk.ac.id/index.php/kredo/index
\end{tabular}

Unsur berita (1) "siapa atau who" berkaitan dengan siapa yang terlibat dalam peristiwa atau kejadian pada berita; (2) "apa atau what" berkaitan dengan peristiwa apa yang terjadi dalam berita; (3) "dimana atau where" merujuk pada tempat kejadian dalam berita; (4) "mengapa atau why" mengarah pada alasan kenapa terjadinya peristiwa tersebut (5); "kapan atau when" berhubungan dengan waktu terjadinya peristiwa tersebut dan (6) "bagaimana atau how" mengacu pada kronologis atau bagaimana peristiwa dalam berita itu terjadi.

\section{F. Ciri-Ciri Kalimat Berita}

Ciri-ciri kalimat berita yang digunakan dalam media cetak, antara lain sebagai berikut (Cahya, 2012:31$35)$.

\section{Baku dan Sederhana}

Kalimat yang baku harus digunakan dalam penulisan isi teks berita. Hal tersebut dikarenakan teks berita yang termuat dalam media massa termasuk ke dalam kelompok tulisan formal. Pilihan kata dalam kalimat yang digunakan harus mudah dipahami oleh pembaca dari berbagai suku bangsa. Kalimat teks berita pun harus sederhana agar mudah dimengerti oleh pembaca dari semua kalangan. Kesederhanaan suatu kalimat dapat dilihat dari penyajian kalimat yang lazim atau lebih umum digunakan.

\section{Menarik}

Kemenarikan kalimat berita sangat berkaitan dengan diksi yang tepat dan sesuai. Ketepatan dan kesesuaian diksi dalam kalimat membuat kalimat menjadi efektif dan menumbuhkan daya tarik pembaca untuk memahami isinya.
Pilihan kata yang digunakan harus kata yang hidup, tumbuh, dan berkembang. Oleh karena itu, teks berita harus ditulis semenarik mungkin dengan tetap memperhatikan kebenaran berita. Agar menarik, bahasa jurnalistik dapat diselingi dengan berbagai variasi kalimat.

\section{Singkat, Padat, dan Lugas}

Kalimat berita harus singkat, padat dan jelas sehinga informasi yang disampaikan dapat dipahami pembaca. Kalimat yang singkat sebaiknya terdiri dari kalimat tunggal. Kalimatnya tidak menjelaskan hal yang terlalu panjang dan bertele-tele. Selanjutnya kalimat berita harus padat informasi dan tepat sasaran. Informasi harus mengandung unsur $5 \mathrm{~W}+1 \mathrm{H}$. Kelugasan sebuah kalimat berita dapat terlihat dari penggunaan kata denotasi atau makna sebenarnya sehingga tidak menimbulkan multitafsir. Kata yang bermakna konotasi atau berbunga-bunga harus dihindari.

\section{Mengutamakan Bentuk Kalimat Aktif}

Teks berita pada dunia jurnalistik sebaiknya ditulis mengutamakan kalimat aktif. Hal tersebut dimaksudkan agar penyampaian informasi dalam berita lebih tegas dan hidup.

\section{Komunikatif}

Jika berita yang disampaikan ingin mudah dpahami dan langsung diterima oleh pembaca maka kalimat yang digunakan harus komunikatif. Kalimat komunikatif disampaikan secara sederhana, singkat, padat, dan lugas dengan menggunakan pilihan kata yang 


Kredo 4 (2020)
KREDO: Jurnal Ilmiah Bahasa dan Sastra
Terakreditasi Sinta 4 berdasarkan Keputusan Direktorat
Jenderal Penguatan Riset dan Pengembangan,
Kementerian Riset, Teknologi dan Pendidikan Tinggi
Republik Indonesia
Nomor: 23/E/KPT/2019. 08 Agustus 2019
https://jurnal.umk.ac.id/index.php/kredo/index

sudah lazim atau populer di kalangan pembaca.

\section{Netral atau Objektif}

Bahasa jurnalistik harus disampaikan secara netral. Netral artinya tidak ada keperpihakan dan objektif. Kata ganti kita dan kami bukan merupakan bentuk kenetralan dalam menyajikan berita.Tidak adanya kata kita dan kami menunjukkan bahwa penulis berita merupakan pihak yang netral, penulis berita merupakan pihak yang berada di luar peristiwa dan tidak terlibat secara subjektif dalam pembicaraan atau tulisan yang dibuatnya.

\section{G. Brainstorming}

\section{Pengertian}

Brainstorming atau curah pendapat adalah metode pengumpulan sejumlah besar gagasan dari sekelompok orang dalam waktu singkat (Sani, 2019:204). Hal ini dimaksudkan bahwa brainstorming adalah salah satu jenis diskusi kelompok yang memiliki tujuan mencari pemecahan masalah. Setiap peserta diskusi diwajibkan mengutarakan gagasan kreatif secara langsung. Para peserta digali ide-ide kreatifnya. Kemudian ide-ide yang digali itu dianalisis untuk menjadi bahan dalam memecahkan masalah (problem solving).

Penerapan brainstorming sering dilakukan dalam format diskusi kelompok yang terdiri dari fasilitator, recorder, dan peserta diskusi. Fasilitator bertugas memandu jalannya diskusi secara menyeluruh dengan mengatur aliran ide peserta. Disisi lain, recorder bertugas mencatat semua ide-ide kreatif yang muncul pada saat sesi brainstorming. Jumlah peserta diskusi idealnya berkisar antara 10-12 orang. Jika peserta diskusi berjumlah lebih dari batas ideal dikhawatirkan menjadi tidak efektif karena membutuhkan waktu yang lama dalam penggalian ide-ide peserta.

Brainstorming tidak hanya digunakan untuk diskusi kelompok, namun dapat dilaksanakan secara individual. Gagasan individu dikemukakan dalam bentuk mind mapping atau peta pikiran. Metode secara individual ini lebih cocok digunakan untuk orang yang bersifat introvert. Hal tersebut dikarenakan orang instrovert cenderung tidak memiliki keberanian mengemukakan pendapatnya secara langsung di muka umum. Walaupun dapat dilaksanakan secara individual, akan tetapi penerapan secara kelompok lebih efektif karena akan memperluas cakupan pemikiran dan lebih banyak memunculkan gagasan secara spontan.

\section{Tujuan dan Manfaat Brainstorming}

Tujuan brainstorming adalah untuk mendapatkan gagasan dan ide-ide baru dari anggota kelompok dalam waktu yang relatif singkat tanpa adanya sifat kritis yang ketat. Sedangkan manfaat melakukan teknik brainstorming dalam suatu tim kerja, diantaranya adalah sebagai berikut.

a. Mengidentifikasi Masalah
Peserta diskusi akan
mengidentifikasi faktor-faktor yang
menyebabkan munculnya masalah yang
dihadapi. Oleh karena itu, teknik
brainstorming cukup efektif digunakan.
Setelah semua peserta mengemukakan
gagasannya mediator bisa membuat
simpulan penyebab permasalahan
tersebut.




Kredo 4 (2020)
KREDO: Jurnal Ilmiah Bahasa dan Sastra
Terakreditasi Sinta 4 berdasarkan Keputusan Direktorat
Jenderal Penguatan Riset dan Pengembangan,
Kementerian Riset, Teknologi dan Pendidikan Tinggi
Republik Indonesia
Nomor: 23/E/KPT/2019. 08 Agustus 2019
https://jurnal.umk.ac.id/index.php/kredo/index

\section{b. Menganalisis Situasi}

Permasalahan dalam diskusi akan dianalisis berdasarkan situasi atau keadaan yang dihadapi tim kerja pada saat ini.

\section{c. MengalirkanIde-ide Baru}

Setiap anggota diskusi memiliki kebebasan mengemukakan idenya dan tidak dibatasi oleh aturan tertentu sehingga mendapatkan ide sebanyak mungkin dari para anggota.

\section{d. Menganalisis Ide-ide}

Ide-ide aktual dan kreatif yang disalurkan peserta dapat dianalisis dalam diskusi panel yang disesuaikan dengan tujuan dan kebutuhan kegiatan.

\section{e. Menentukan Alternatif Pemecahan Masalah}

Ide yang sudah dianalisis bersama dalam diskusi panel kemudian ditentukan alternatifnya berdasarkan kesepakatan. Ide-ide yang ditentukan harus relevan untuk memecahkan masalah.

\section{f. Merencanakan Langkah-langkah dan Kegiatan yang akan dilakukan untuk Memperbaiki Masalah}

Teknik brainstorming ini bermanfaat untuk membuat perencanaan langkah-langkah kegiatan yang berkelanjutan. Langkah-langkah ini disusun sebagai usaha untuk memperbaiki masalah berdasarkan gagasan atau sumbang saran dari peserta.

\section{Metode Brainstorming}

Menurut Laisa (2019), beberapa metode yang dapat digunakan dalam 58 | Jurnal Kredo Vol. 4 No. 1 Oktober 2020 penggalian ide guna mempermudah jalannya diskusi antara lain:

\section{a. Putaran Bebas (Free Wheel)}

Metode putaran bebas sangat mengutamakan kebebasan anggota kelompok dalam berbicara di muka umum. Hal itu dilakukan tanpa ada larangan sehingga pendapat dapat disalurkan. Namun kebebasan berpendapat tetap memperhatikan etika berbicara yaitu peserta mesti mengangkat tangan kepada fasilitator. Jika sudah mendapat persetujuan dari fasilitator, peserta baru mulai berbicara.

Peserta juga diberi jatah waktu yang sama dalam setiap topik saat berbicara. Hal ini dilakukan supaya tidak ada peserta yang memonopoli dalam diskusi. Jika ada peserta yang belum mendapatkan giliran berbicara maka akan diulang putarannya untuk memberikan peluang kepada mereka.

\section{b. Putaran Teratur (Round Robin)}

Metode putaran teratur ini mengatur anggota diskusi dalam berbicara. Anggota diskusi hanya dapat mengutarakan pemikirannya mengikuti aturan dan giliran. Peserta hanya diizinkan mengemukakan satu ide dalam putaran diskusi dan sesuai gilirannya. Kemudian dilaksanakan dari kanan ke kiri.

Metode ini akan melakukan beberapa kali putaran sampai semua ide peserta tergali. Jika dalam putaran ada peserta belum memiliki ide saat tiba gilirannya, maka orang tersebut dapat dilewati dan mempersilahkan giliran selanjutnya.

\section{Teknik Brainstorming}

Beberapa teknik dapat digunakan dalam brainstorming seperti teknik 


Kredo 4 (2020)
KREDO: Jurnal Ilmiah Bahasa dan Sastra
Terakreditasi Sinta 4 berdasarkan Keputusan Direktorat
Jenderal Penguatan Riset dan Pengembangan,
Kementerian Riset, Teknologi dan Pendidikan Tinggi
Republik Indonesia
Nomor: 23/E/KPT/2019. 08 Agustus 2019
https://jurnal.umk.ac.id/index.php/kredo/index

freewriting, listing/bulleting, dan cubing. Adapun uraian singkat mengenai teknik-teknik tersebut sebagai berikut.

\section{a. Freewriting}

Teknik ini dilakukan dengan cara menuliskan gagasan-gagasan original dalam selembar kertas baik ditulis tangan ataupun diketik. Peserta tidak perlu mengkhawatirkan masalah idenya, baik dari muatan idenya ataupun penulisannya. Ide yang muncul secara spontan langsung dituliskan dan disesuaikan dengan waktu yang telah ditentukan.

\section{b. Listing/Bulleting}

Teknik listing digunakan dengan cara membuat daftar yang berisi ide-ide yang muncul. Ide-ide tersebut disusun berdasarkan topik-topik tertentu. Hal ini bertujuan untuk meluaskan perspektif berkenaan dengan masing-masing topik.

\section{c. Cubing}

Teknik cubing dapat memungkinkan pengembangan topik dari enam arah yaitu deskripsi masalah, perbandingan, penyesuaian, analisis masalah, penerapan, dan adanya pendapat pro dan kontra yang muncul berkenaan dengan problem solving yang akan digunakan.

\section{d. Dictionaries, Thesauruses, dan Encyclopedias \\ Teknik ini menggunakan bantuan} Kamus, tesaurus atau ensiklopedi digunakan dalam teknik ini untuk mengembangkan pemikiran berdasarkan ribuan kata yang ada dalam kamus tersebut. Kamus, tesaurus, dan ensiklopedi merupakan perkumpulan perbedaharaan kata dan istilah yang dapat dijadikan sebagai kata kunci untuk memecahkan masalah. Kata kunci akan artikan oleh kamus dan diikuti dengan alternatif kata-kata lain dalam penggunaannya.

\section{e. Journalistic Questions}

Prinsip 5W dan $1 \mathrm{H}$ meliputi What, Who, When, Where, Why, dan How yang dipakai para wartawan dalam membuat berita juga digunakan dalam teknik ini. Masing-masing elemen dituliskan dalam lembar yang berlainan. Lalu peserta dapat memasukkan ide-ide barunya untuk menjawab elemen pertanyaan tersebut.

\section{METODE PENELITIAN}

Metode yang digunakan pada penelitian ini adalah eksperimen. Menurut Sugiyono (2012:72), metode eksperimen adalah "Metode penelitian yang digunakan untuk mencari pengaruh perlakuan tertentu terhadap yang lain dalam kondisi yang terkendalikan". Desain yang digunakan praeksperimental. Dalam penelitian ini peneliti secara langsung bereksperimen untuk mencari hubungan sebab akibat antarvariabel. Adapun desain penelitian yang digunakan dalam penelitian ini adalah: tes awal-tes akhir kelompok tunggal (The One Group Pretest Posttest design). Pertama dilakukan pengukuran, lalu dikenakan perlakuan untuk jangka waktu tertentu, kemudian dilakukan pengukuran untuk kedua kalinya. Untuk menyatakan apakah hipotesis ditolak atau diterima, dilakukan perhitungan uji$\mathrm{t}$ dengan program SPSS 17 dengan teknik Paired Sample t test.

Populasi dalam penelitian ini adalah seluruh mahasiswa semester VI Program Studi PBSI yang berjumlah 137 mahasiswa. Dalam penelitian ini sampel diambil dengan menggunakan sampel 


Kredo 4 (2020)
KREDO: Jurnal Ilmiah Bahasa dan Sastra
Terakreditasi Sinta 4 berdasarkan Keputusan Direktorat
Jenderal Penguatan Riset dan Pengembangan,
Kementerian Riset, Teknologi dan Pendidikan Tinggi
Republik Indonesia
Nomor: 23/E/KPT/2019. 08 Agustus 2019
https://jurnal.umk.ac.id/index.php/kredo/index

random sampling. Peneliti mendapatkan kelas A.6.1 sebagai sampel dalam penelitian dengan jumlah sampel sebanyak 27 orang. Adapun langkahlangkah yang dilakukan dalam penganalisisan data dalam penelitian ini sebagai berikut.

1. Mengumpulkan data dengan teknik tes tertulis berbentuk uraian.

2. Memberikan penilaian hasil menulis teks berita dengan berpedoman pada kriteria penilaian berdasarkan kriteria penilaian menulis teks berita yaitu kelengkapan isi berita (mengandung $5 \mathrm{~W}+1 \mathrm{H})$, keruntutan pemaparan, penggunaan kalimat, kosakata, kemenarikan judul, ketepatan penggunaan ejaan dalam berita (Nurgiyantoro, 2012:433) disesuaikan dengan kebutuhan penelitian.

3.Mengetahui kemampuan mahasiswa sampel per individu. Perhitungan pada tahap ini berpedoman pada rumus sebagai berikut.

Nilai $=\underline{\text { Skor Mentah }} \times 100$

Skor Maksimum Ideal

4. Menentukan nilai rata-rata mahasiswa dalam menulis dengan rumus sebagai berikut.

$$
\mathrm{X}=\frac{\sum \mathrm{X}}{N}
$$

Keterangan:

$\overline{\mathrm{X}}=$ Kemampuaan mahasiswa rata-rata;

$\sum \mathrm{X}=$ Jumlah keseluruhan kemampuan mahasiswa;

$N=$ Banyak mahasiswa (Nurgiyantoro, 2012: 219)

5. Mengkonversikan kemampuan dengan nilai yang sudah diperoleh dengan skala penilaian pada tabel $1 \mathrm{di}$ bawah ini.

Tabel 1. Pedoman Konversi Nilai

\begin{tabular}{|c|c|}
\hline Persentase & Predikat \\
\hline $80-100$ & Sangat baik \\
\hline
\end{tabular}

60 | Jurnal Kredo

Vol. 4 No. 1 Oktober 2020

\begin{tabular}{|c|c|}
\hline $70-79$ & Baik \\
\hline $56-69$ & Cukup \\
\hline $0-55$ & Kurang \\
\hline
\end{tabular}

6. Melakukan analisis dan interpretasi hasil analisis.

7. Membuat simpulan.

Penelitian ini dilaksanakan di Program Studi PBSI sebanyak 6 kali. 1 kali pre-test pada tanggal 4 Maret 2019, ekperimen pada bulan tanggal 7, 12, 15, 19 Maret 2019, dan pos-test pada tanggal 22 Maret 2019.

\section{HASIL DAN PEMBAHASAN}

\section{Tes Sebelum Menggunakan Metode Brainstorming (Pre-Test) \\ Berdasarkan hasil penelitian} mahasiswa semester VI Program Studi Pendidikan Bahasa dan Sastra Indonesia FKIP Unbara yang berjumlah 27 orang diperoleh data nilai menulis sebelum diterapkan metode brainstorming.

Dari penilaian setiap indikator di atas menunjukkan bahwa pembelajaran sebelum menggunakan metode brainstorming masih memiliki hasil yang kurang baik. Hal ini dibuktikan dengan hasil total setiap indikator yang diujikan dimana yang memperoleh skor 80-100 dengan predikat sangat baik, tidak ada satupun yang mendapatkannya pada pre-test, skor 70-79 terdapat 6 orang mahasiswa yang memperolehnya dengan predikat baik. Total skor terbanyak terdapat pada rentang skor 5669 yaitu sebanyak 16 mahasiswa dengan predikat cukup, dan terdapat 5 orang mahasiswa yang memiliki total skor antara 0-55 dengan predikat kurang.

Jika konversi nilai tersebut digambarkan dalam bagan, maka bagan 


Kredo 4 (2020)
KREDO: Jurnal Ilmiah Bahasa dan Sastra
Terakreditasi Sinta 4 berdasarkan Keputusan Direktorat
Jenderal Penguatan Riset dan Pengembangan,
Kementerian Riset, Teknologi dan Pendidikan Tinggi
Republik Indonesia
Nomor: 23/E/KPT/2019. 08 Agustus 2019
https://jurnal.umk.ac.id/index.php/kredo/index

yang muncul sebagai berikut.

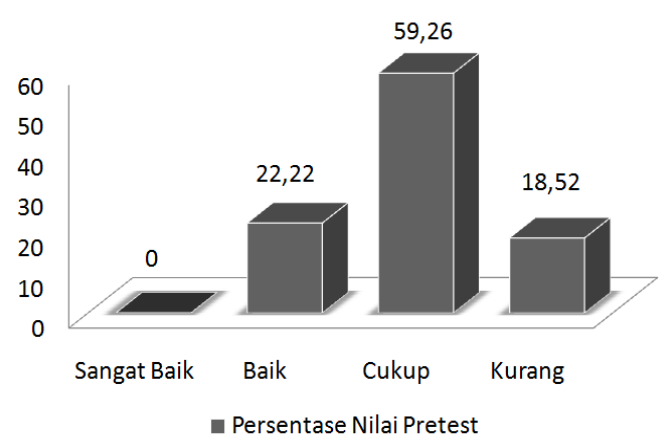

Bagan 1. Persentase Nilai Hasil Pre-test

Dari bagan presentase di atas dapat dideskripsikan bahwa sebelum menggunakan metode brainstorming mahasiswa yang mendapatkan predikat sangat baik tidak ada. Mahasiswa yang mendapatkan nilai dengan predikat baik ada 22,22\%, mahasiswa yang mendapatkan nilai dengan predikat cukup 59,6\%, dan mahasiswa mendapatkan nilai dengan predikat kurang ada 18,52\%. Berdasarkan uraian di atas dapat disimpulkan bahwa nilai rata-rata pre-test adalah $64,4 \%$ dengan predikat cukup.

\section{Tes Setelah Menggunakan Model Brainstorming (Post-Test)}

Melihat hasil penilaian menulis berita yang kurang baik saat pre-test, maka peneliti memberikan metode baru yang diharapkan dapat mengubah hasil belajar. Seperti yang telah diuraikan di awal, penelitian menggunakan metode brainstorming untuk melihat peningkatan kemampuan menulis berita mahasiswa semester VI. Metode ini digunakan pada kelas yang sama serta dengan indikator penilaian yang sama pula. Dari penilaian setiap indikator di atas menunjukkan bahwa pembelajaran setelah menggunakan metode brainstorming memiliki hasil yang baik. Hal ini dibuktikan dengan hasil total setiap indikator yang diujikan di mana yang memperoleh skor 80-100 dengan predikat sangat baik, saat pre-test tidak ada satu pun yang mendapatkannya namun pada post-test terdapat 22 mahasiswa. Skor 70-79 terdapat 6 orang mahasiswa yang memperolehnya dengan predikat baik. Selanjutnya tidak terdapat total skor pada rentang skor 56-69 dan total skor antara 0-55 dengan predikat cukup dan kurang. Persentase hasil nilai post-test dapat dilihat pada Bagan 2.

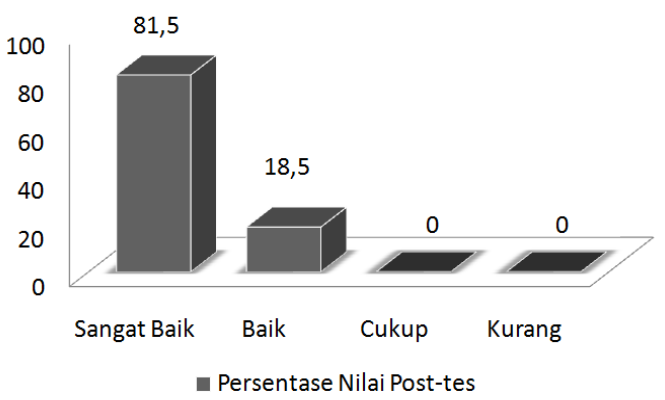

Bagan 2. Persentase Nilai Hasil Pos-test

Berdasarkan bagan persentase di atas dapat dideskripsikan bahwa terdapat perubahan setelah menggunakan metode brainstorming di mana 81,5\% mahasiswa mendapatkan predikat sangat baik dalam menulis berita; 18,5\% mahasiswa mendapatkan predikat baik. Serta tidak terdapat satu pun mahasiswa yang mendapatkan nilai dengan predikat cukup dan predikat kurang dalam menulis teks berita. 
Kredo 4 (2020)

KREDO: Jurnal Ilmiah Bahasa dan Sastra

Terakreditasi Sinta 4 berdasarkan Keputusan Direktorat Jenderal Penguatan Riset dan Pengembangan, Kementerian Riset, Teknologi dan Pendidikan Tinggi

Republik Indonesia

Nomor: 23/E/KPT/2019. 08 Agustus 2019

https://jurnal.umk.ac.id/index.php/kredo/index

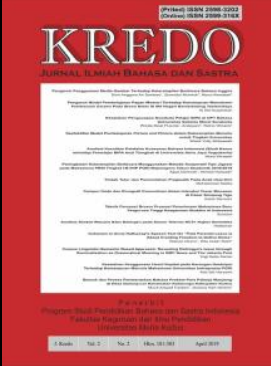

\section{Keefektifan Metode Brainstorming terhadap Kemampuan Menulis Teks Berita}

Pembelajaran metode brainstorming dalam implementasinya didapatkan data skor pre-test dan post-test kelas. Berikut bagan perbedaan antara persentase pretest dan post-test dari jumlah setiap indikator. Persentase hasil pre-test dan post-test dapat dilihat pada bagan 3 .

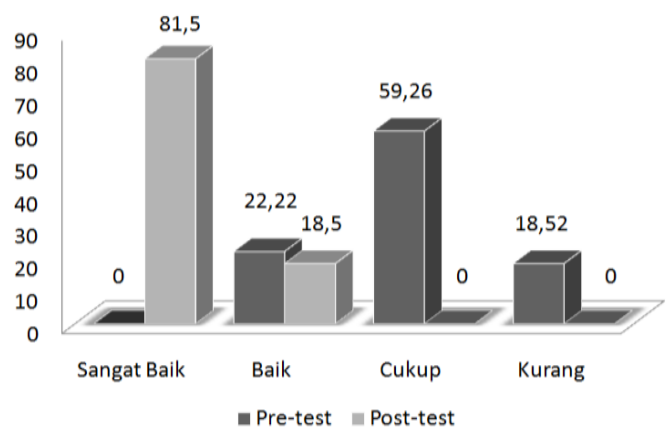

Bagan 3. Perbandingan Persentase Pre-test dan Post-test

Berdasarkan bagan persentase perbandingan di atas dapat kita deskripsikan bahwa terdapat perbedaan yang signifikan antara hasil pre-test dan hasil post-test. Di mana dalam hasil pretest tidak terdapat mahasiswa yang mendapat predikat sangat baik. Sedangkan hasil post-test mahasiswa yang mendapatkan nilai dengan predikat sangat baik mencapai $81,5 \%$. Pada predikat baik, hasil post-test $18,5 \%$ sementara pre-test 22,22\%. Pada hasil penilaian yang sangat menarik adalah hasil penilaian dengan predikat cukup dan kurang, di mana pada pre-test terdapat $59,26 \%$ dan 18,52 mahasiswa yang mendapat predikat tersebut. Sementara setelah diberikan perlakuan dengan menggunakan metode brainstorming tidak terdapat satu pun mahasiswa yang mendapatkan predikat tersebut.

Hasil uji t untuk data keefektifan metode brainstorming dapat dilihat pada tabel 2 di bawah ini.

Tabel 2. Paired Sample t-Test

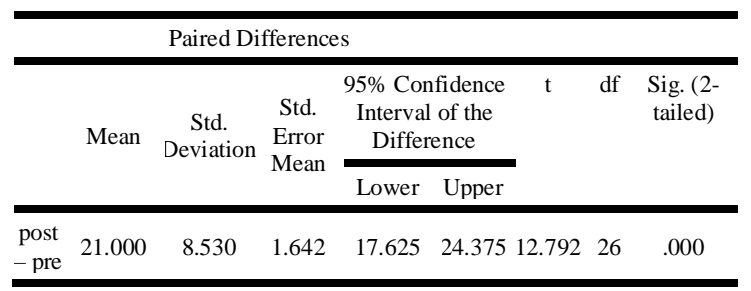

Untuk melihat efektifitas metode pembelajaran brainstorming dilakukan dengan menggunakan uji-t, untuk melihat apakah ada perbedaan yang signifikan nilai yang diperoleh saat pembelajaran menggunakan pembelajaran secara konvensional dan dan pembelajaran dengan metode brainstorming. Perhatikan tabel 3 berikut.

Tabel 3.Hasil Perhitungan Uji t keefektifan metode

\begin{tabular}{cccc} 
Data & thitung & $\begin{array}{c}\text { tabel } \\
(0.05: 25)\end{array}$ & Keputusan $\mathrm{Uji}\left(\mathrm{H}^{o}\right)$ \\
\hline $\begin{array}{c}\text { Pembelajaran } \\
\begin{array}{c}\text { metode } \\
\text { brainstorming }\end{array}\end{array}$ & 12.792 & 2.06 & $\mathrm{H}^{o}$ ditolak \\
\hline
\end{tabular}

Sumber: Data perhitungan uji t

Tabel 3 menunjukkan bahwa $t_{\text {hitung }}>$ $t_{\text {tabel }}$ (0.05:27). Oleh karena itu, dapat disimpulkan bahwa ada perbedaan kemampuan menulis antara metode konvensional dan menggunakan metode pembelajaran brainstorming. Selain itu, dapat disimpulkan bahwa ada perbedaan skor rata-rata dari nilai pretest menggunakan metode pembelajaran 


Kredo 4 (2020)
KREDO: Jurnal Ilmiah Bahasa dan Sastra
Terakreditasi Sinta 4 berdasarkan Keputusan Direktorat
Jenderal Penguatan Riset dan Pengembangan,
Kementerian Riset, Teknologi dan Pendidikan Tinggi
Republik Indonesia
Nomor: 23/E/KPT/2019. 08 Agustus 2019
https://jurnal.umk.ac.id/index.php/kredo/index

brainstorming lebih tinggi daripada metode konvensional. Skor rata-rata post-test menggunakan metode brainstorming dalam pembelajaran 84,4dan skor rata-rata pre-test adalah 64,44. Itu artinya pembelajaran dengan menggunakan metode brainstorming lebih efektif dalam pembelajaran menulis teks berita.

\section{PEMBAHASAN}

Metode pembelajaran brainstorming yang digunakan dalam penelitian di Program Studi PBSI FKIP UNBARA efektif dalam meningkatkan kemampuan menulis teks berita mahasiswa semester VI. Hal ini ditunjukkan dengan tingkat pencapaian tujuan pembelajaran. Penggunaan metode brainstorming yang efektif dapat dilihat dari aktivitas mahasiswa yang meningkat dalam kegiatan berbicara dan menulisnya.

Ada beberapa syarat utama pembelajaran dikatakan efektif yaitu (1) mahasiswa mencurahkan waktu belajar yang tinggi dalam kegiatan belajar mengajar; (2) mahasiswa memiliki ratarata yang tinggi dalam melaksanakan tugas; (3) kandungan materi yang diajarkan dan kemampuan mahasiswa memiliki ketepatan. Artinya keberhasilan dalam belajar diutamakan; (4) Suasana belajar yang kondusif, akrab, dan positif terus dikembangkan.

Pada penelitian ini, pendekatan metode brainstorming efektif digunakan dalam pembelajaran di kelas. Hal itu dapat dapat dilihat dari tingkat keberhasilan yang sudah tercapai dan adanya motivasi yang meningkat pada mahasiswa untuk belajar. Efektifnya pembelajaran metode brainstorming dapat diketahui dari aktivitas mahasiswa yang lebih mandiri, aktif, dan terampil dalam berbicara dan menulis khususnya menulis berita. Penjelasan tersebut diperkuat dari hasil pembelajaran nilai post-testyang menunjukkan hasil lebih baik dibandingkan nilai pre-test. Adapun nilai yang diperoleh dengan skor ratarata post-test 84,44 dan skor rata-rata pre-test adalah 64,44.

Sementara itu, peneliti mendapatkan temuan lain dalam penelitian ini berkaitan dengan aspek penilaian. Ratarata nilai yang diperoleh untuk aspek $5 \mathrm{~W}+1 \mathrm{H}$ (pre-test 17,4, post-test 26,67), aspek keruntutan pemaparan (pre-test $11,15$, post-test 13,70$)$, aspek ketepatan kalimat (pre-test 11,07, post-test 13,52), aspek pemilihan kata (pre-test 13,33, post-test 14,26), aspek kemenarikan judul (pre-test 5,56 post-test 8,15), aspek ejaan (pre-test 5,3, post-test 8,15). Adapun perbandingan hasil rata-rata penilaian dapat dilihat dari bagan 4 di bawah ini.

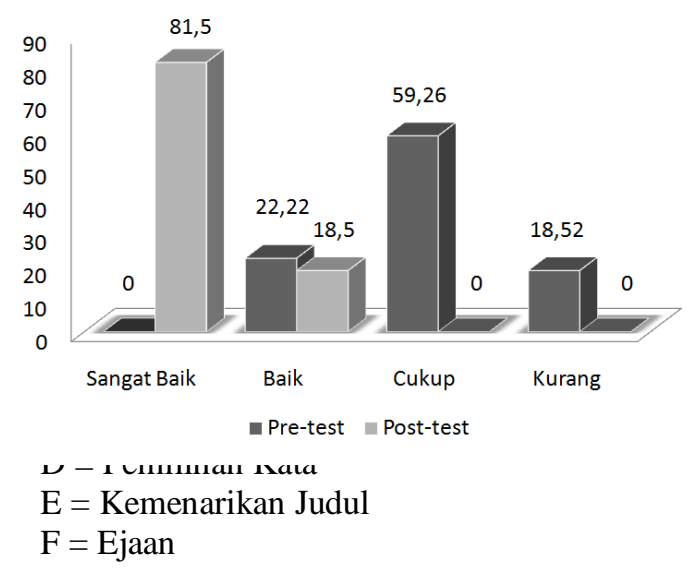

Berdasarkan uraian dan bagan 4 di atas diketahui bahwa nilai mahasiswa rata-rata meningkat dari pre-test ke post- 


Kredo 4 (2020)
KREDO: Jurnal Ilmiah Bahasa dan Sastra
Terakreditasi Sinta 4 berdasarkan Keputusan Direktorat
Jenderal Penguatan Riset dan Pengembangan,
Kementerian Riset, Teknologi dan Pendidikan Tinggi
Republik Indonesia
Nomor: 23/E/KPT/2019. 08 Agustus 2019
https://jurnal.umk.ac.id/index.php/kredo/index

test. Peningkatan yang paling signifikan adalah penulisan unsur $\mathrm{SW}+1 \mathrm{H}$ dalam teksa berita. Sementara itu nilai ejaan masih perlu ditingkatkan kembali. Ejaan sangat penting dalam sebuah tulisan karena menjadi penanda agar komunikasi tulis tidak menimbulkan salah tafsir dan mudah dipahami oleh pembaca. Adapun ejaan yang diterapkan harus berlandaskan pada Pedoman Umum Ejaan Bahasa Indonesia (PUEBI). Fungsi Ejaan sangat penting yaitu sebagai landasan pembakuan tata bahasa, landasan pembakuan kosakata dan peristilahan sekaligus penyaring penetrasi unsur bahasa asing (Wibowo, 2007).

Berdasarkan penjelasan di atas dapat disimpulkan bahwa pendekatan metode brainstorming efektif terhadap kemampuan menulis teks berita mahasiswa semester VI Program Studi PBSI FKIP Unbara. Berdasarkan aspekaspek penilaian saat pretes kemampuan menulis mahasiswa masih kurang baik, namun setelah diterapkan pendekatan metode brainstorming (post-test) dalam pembelajaran, kemampuan mahasiswa sudah dalam kategori sangat baik, walaupun dalam aspek ejaan masih ada beberapa mahasiswa yang belum baik. Kondisi ini dapat diatasi dengan latihanlatihan yang lebih intensif sehingga mahasiswa tersebut semakin mahir menggunakan ejaan dalam kegiatan menulisnya khususnya menulis teks berita.

\section{SIMPULAN}

Berdasarkan hasil penelitian dan pembahasan ditemukan adanya perbedaan skor rata-ratadari nilai pretest dan pos-test. Dalam penelitian ini diperoleh nilai yang menjelaskan bahwa kemampuan menulis berita mahasiswa semester VI Program Studi PBSI FKIP UNBARA setelah menggunakan pendekatan metode brainstorming lebih tinggi dari sebelum menggunakan metode brainstorming. Skor rata-rata post test 84,44 dan skor rata-rata pre test adalah 64,44. Jadi dapat disimpulkan bahwa pendekatan metode brainstorming dapat meningkatkan kemampuan menulis teks berita mahasiswa. Hal ini berarti hipotesis yang menyatakan bahwa pendekatan metode brainstorming efektif terhadap kemampuan mahasiswaSemester VI Program Studi PBSI FKIP UNBARA menulis teks berita mahasiswa terbukti kebenarannya.

Hasil penelitian ini juga diharapkan dapat memberikan implikasi bahwa metode pembelajaran brainstorming dapat digunakan dalam meningkatkan pembelajaran keterampilan berbahasa khususnya menulis. Dosen pengampu mata kuliah keterampilan, khususnya mata kuliah menulis dapat menerapkan berbagai pendekatan, model, dan metode yang bervariasi dalam pembelajaran. Hal ini dimaksudkan agar mahasiswa lebih terampil dalam menulis. Sementara itu, bagi mahasiswa harus terus berlatih dan memberanikan diri untuk menulis dalam berbagai situasi sehingga mahasiswa dapat terampil dalam menulis. 


Kredo 4 (2020)
KREDO: Jurnal Ilmiah Bahasa dan Sastra
Terakreditasi Sinta 4 berdasarkan Keputusan Direktorat
Jenderal Penguatan Riset dan Pengembangan,
Kementerian Riset, Teknologi dan Pendidikan Tinggi
Republik Indonesia
Nomor: 23/E/KPT/2019. 08 Agustus 2019
https://jurnal.umk.ac.id/index.php/kredo/index

\section{DAFTAR PUSTAKA}

Alfarisi, Rahman Saleh dan Suseno. 2019. "Pengembangan Buku Pengayaan Menulis Teks Anekdot Bermuatan Cinta Tanah Air" dalam Jurnal Kredo Volume 3 Nomor 1 Tahun 2019. https://jurnal.umk.ac.id/index.php/kredo/article/view/3950

Awi, Solichin M. 2011. Tentang Menulis, Mengapa Menulis, dan Menulislah!. Yogyakarta: New Diglossia.

Cahya, Inung S. 2012. Menulis Berita di Media Massa. Klaten: PT Intan Sejati

Emilda. 2019. "Pengaruh Pemanfaatan Lingkungan Sekolah terhadap Peningkatan Kemampuan Siswa dalam Menulis Puisi" dalam Jurnal Kredo Volume 3 Nomor 1 Tahun 2019. https://jurnal.umk.ac.id/index.php/kredo/article/view/3082

Laisa, Amalia. 2019. Apa yang dimaksud dengan Pembelajaran Metode Brainstorming? https://www.dictio.id/t/apa-yang-dimaksud-dengan-pembelajaranmetode-brainstorming/120139 diakses tanggal 22 September 2020

Harianti, Asni dan Yola Margareta. 2014. "Pengembangan Kreativitas Mahasiswa dengan Menggunakan metode Brainstorming dalam Mata Kuliah Kewirausahaan" dalam Jurnal Manajemen Volume 13 Nomor 2 Tahun 2014 https://media.neliti.com/media/publications/113881-ID-pengembangan-kreativitasmahasiswa-denga.pdf

Jauhari, Haris. 2012. Jurnalisme Televisi Indonesia. Jakarta: Kepustakaan Populer Gramedia.

Lestari, Riska Fita. 2019. "Kohesi dan Koherensi Paragraf dalam Karangan Narasi Mahasiswa Teknik Angkatan 2017 Universitas PGRI Banyuwangi” dalam Jurnal $\begin{array}{llllll}\text { Kredo } & \text { Volume } & 3 & \text { Nomor } & 1 & \text { Tahun }\end{array}$ https://jurnal.umk.ac.id/index.php/kredo/article/view/3924

Nurgiyantoro, Burhan. 2012. Penilaian Pembelajaran Bahasa Berbasis Kompetensi. Cet.ke-3. Yogyakarta: BPFE.

Rohmadi, Muhammad. 2011. Jurnalistik Media Cetak. Surakarta: Cakrawala Media

Rosidi, Imron. 2009. Menulis... Siapa Takut?. Yogyakarta: Kanisius.

Sani, Ridwan Abdullah. 2019. Strategi Belajar Mengajar. Depok: Rajawali Pers. 


Kredo 4 (2020)
KREDO: Jurnal Ilmiah Bahasa dan Sastra
Terakreditasi Sinta 4 berdasarkan Keputusan Direktorat
Jenderal Penguatan Riset dan Pengembangan,
Kementerian Riset, Teknologi dan Pendidikan Tinggi
Republik Indonesia
Nomor: 23/E/KPT/2019. 08 Agustus 2019
https://jurnal.umk.ac.id/index.php/kredo/index

Sugiyono. 2012. Metode Penelitian: Pendekatan Kualitatif, Kuantitatif dan R\&D. Bandung: Alfabeta.

Suparno dan Mohamad Yunus. 2002. Keterampilan Dasar Menulis. Jakarta: Universitas Terbuka.

Trianto. 2010. Model Pembelajaran Terpadu. Yogyakarta: Graha Ilmu.

Wibowo, Wahyu. 2007. Menjadi Penulis dan Penyunting Sukses: Langkah Jituerangkai Kata agar Komunikatif, Hidup, dan Memikat. Jakarta: PT Bumi Aksara.

Widyawati, Wiwik Yully. 2019. "Keefektifan Model Pembelajaran Picture and Picture dalam Keterampilan Menulis untuk Tingkat Universitas" dalam Jurnal Kredo $\begin{array}{llllll}\text { Volume } & 2 & \text { Nomor } & 2 & \text { Tahun } & 2019 .\end{array}$ https://jurnal.umk.ac.id/index.php/kredo/article/view/3027/1600 